\title{
PERAN PEMERINTAH DALAM PENGEMBANGAN POTENSI PARIWISATA DI AREA BRANCA METIAUT, DILI
}

\author{
Zeferino Martins, Syamsul Alam Paturusi, Ida Bagus Ketut Surya \\ Universitas Udayana
}

\begin{abstract}
Area Branca Metiaut is one of the potential tourism areas in the Dili District the Capital City of East Timor, but it has not well developed. Thus the role of the government is needed to engage public participation in Area Branca Metiaut towards better development with the emphasis on aspects of sustainability. This study used a qualitative-descriptive approach. The data were collected by using observation technique and in-depth interviews. The technical data analysis used qualitativedescriptive and SWOT matrix analysis. The study shows that there are factors that support and hindrance the attempt to develop Area Branca Metiaut as tourism destination. The supporting factors include the nature beauty of the area with stunning white sandy beaches. The obstacle factors include the lack of infrastructure, human resources, and tourism facilities. Through SWOT analysis it was selected strategies including the need of the government to set up regulation and policy in providing infrastructure and in encouraging community in tourism awareness.
\end{abstract}

Keywords : tourism development, role of government, the Village of Metiaut, Timor Leste

\begin{abstract}
Abstrak
Aera Branca Metiaut merupakan salah satu kawasan wisata potensial di Kabupaten Dili Ibukota Timor Timur yang kaya akan keindahan alam namun tidak berkembang dengan baik untuk daya tarik wisata. Dengan demikian peran pemerintah diperlukan untuk meningkatkan partisipasi masyarakat untuk mengembangkan daerahnya sebagai daya tarik wisata. Penelitian ini mengkaji peran pemerintah dalam pengembangan Aera Branca menggunakan pendekatan kualitatif-deskriptif. Data dikumpulkan dengan menggunakan teknik observasi dan wawancara mendalam. Analisis data teknis yang digunakan
\end{abstract}


kualitatif-deskriptif dan analisis matriks SWOT. Studi ini menunjukkan bahwa ada faktor-faktor yang mendukung dan menghalangi dalam upaya untuk mengembangkan Area Branca Metiaut sebagai tujuan wisata. Faktor pendukung meliputi keindahan alam dari daerah dengan pantai berpasir putih yang menakjubkan. Faktor-faktor kendala termasuk kurangnya infrastruktur, sumber daya manusia, dan fasilitas pariwisata. Melalui analisis SWOT itu dipilih strategi terutama pentingnya pemerintah untuk memainkan perannya terutama dalam regulasi dan kebijakan dalam penyediaan infrastruktur dan mendorong masyarakat untuk meningkatkan sadar wisata.

Kata kunci: pengembangan pariwisata, peran pemerintah, Desa Metiaut, Timor Leste

\section{Pendahuluan}

Negara Republica Democratica Timor-Leste adalah sebuah Negara kecil yang secara unilateral memproklamasikan kemerdekaannya pada tanggal, 28 Nopember 1975 dan baru berdaulat penuh pada tangal, 20 Mei 2002. Sejak itu pemerintah dan rakyat Timor-Leste sudah memiliki tekad untuk mewujudkan stabilitas kehidupan masyarakat yang aman, tentram dan sejahtera yang mana telah dicita-citakan seperti termuat pada pasal (6) Bagian (e) dan (i) dalam konstitusi República Demokrática Timor-Leste (UUD RDTL, 2002).

Negara Republica Democratica Timor-Leste memiliki kekayaan alam yang melimpah dengan berbagai macam kebudayaan, adat istiadat, agama serta banyak pantai yang memiliki keindahan yang sangat unik seperti salah satunya di Area Branca Desa Metiaut, Dili. Hal ini tentunya dapat dimanfaatkan dalam bidang kepariwisataan sebagai sektor komoditi yang sangat bagus bagi perekonomian dan sebagai penghasil devisa atau pendapatan Negara kedua setelah minyak bumi dan gas alam.

Area Branca merupakan salah satu kawasan pariwisata yang berpotensial di Area Branca Desa Metiaut, Kecamatan Cristo Rei, Kabupaten Dili Ibu Kota Negara Timor Leste, namun belum berkembang dengan baik. Mengingat masih belum berkembang maka memerlukan peran pemerintah untuk mengikutsertakan partisipasi masyarakat dalam pengembangan Area Branca yang lebih baik lagi dengan menitikberatkan pada aspek berkelanjutannya.

Dalam pengembangan suatu daerah atau kawasan menjadi sebuah destinasi pariwisata tentu harus didukung dengan sumber daya manusia yang memadai baik secara kualitas maupun kuantitas. Sumber daya manusia diakui sebagai salah satu komponen yang sangat penting dalam pembangunan pariwisata (Pitana dan Diarta, 2007: 72). Selain itu peran 
pemerintah, bagaimana memotivasi atau mendorong Lembaga Swadaya Masyarakat (LSM) serta masyarakat untuk ikut berpartisipasi dalam mengembangkan kepariwisataan di lokasi tersebut.

Sasaran pembangunan pariwisata pada dasarnya adalah untuk meningkatkan status pariwisata dari sub sektor pembangunan menjadi sektor pembangunan andalan yang mampu menggiatkan perekonomian dan sektor-sektor lain yang terkait. Sebagai suatu industri jasa, pariwisata diharapkan dapat berfungsi sebagai agen dalam pembangunan (Yoeti, 2008: 35).

Weaver dan Opperman (dalam Pitana, 2005: 44), mengemukakan bahwa perencanaan pengembangan dan pemasaran suatu destinasi wisata memerlukan kerjasama dan koordinasi berbagai pihak pejabat pemerintah, perencana fisik, arsitek, analisis financial, investor, pakar ekonomi, sosiolog, arkeolog dan elemen yang terkait di dalamnya.

Peran pemerintah sangat diperlukan dalam membuat regulasi, melakukan pengawasan, membuat kebijakan, karena kebijakan merupakan perencanaan jangka panjang yang perlu dilakukan oleh pemerintah Timor-Leste, khususnya kabupaten Dili dalam mengembangkan kepariwisataan di daya tarik wisata Area Branca, Desa Metiaut, Dili. Selain dari peran pemerintah yang telah disebutkan diatas, peran pemerintah mempersiapkan sumber daya manusia. Karena sumber daya manusia (SDM) merupakan salah satu faktor pendukung pemerintah dalam pengembangan suatu destinasi pariwisata.

Dalam mendukung jalannya kepariwisataan di Timor-Leste, pemerintah setempat telah menyediakan beberapa fasilitas penunjang antara lain bandara internasional Nicolao Lobato yang terletak di Ibu Kota Negara Timor-Leste yaitu Dili. Untuk maskapai penerbangan dari Indonesia menuju Timor-Leste telah tersedia Airline, Citilink, Sriwijaya Air, dan Nam Air. Untuk maskapai penerbangan dari Australia menuju Timor-Leste telah tersedia penerbangan Air North dan untuk maskapai penerbangan dari Singapura menuju Timor Leste telah tersedia Sriwijaya Air.

Penulisan artikel ini bertujuan untuk mengetahui peran pemerintah dalam pengembangan potensi pariwisata di Area Branca Desa Metiaut, Dili, Faktor pendukung dan penghambat pemerintah dalam mengembangkan potensi pariwisata di Area Branca Desa Metiaut, Dili dan Strategi Pemerintah untuk mengembangkan Potensi Pariwisata di Area Branca Desa Metiaut, Dili.

\section{Teori dan Metode Penelitian}

Ada dua teori yang digunakan dalam membahas masalah penelitian ini yaitu teori fungsional dan teori strategi.

Dalam mengkaji masalah ini teori fungsional masyarakat dalam pranata sosial sebagai sistem dimana seluruh bagiannya saling ketergantungan satu 
sama lainnya dan bekerjasama guna menciptakan keseimbangan. Unsur keseimbangan ini merupakan kunci dalam fungsional sehingga mengarah pada penciptaan status quo. Di samping itu, teori fungsional ini sekaligus sebagai teori stabilitas sosial dan konsensus normatif, sebagaimana dikemukakan oleh Parsons (dalam Campbell, 1994:225), yang memandang masyarakat sebagai suatu sistem sosial yang terdiri atas bagian-bagian atau unit-unit sosial seperti lembaga, kelompok, kelas dan organisasi yang saling berhubungan dan terpadu, struktur dan fungsi unit-unit sosial yang dinamis, kehidupan dalam sistem sosial disatupadukan oleh adanya konsensus di antara anggota masyarakat itu terhadap nilai-nilai dan tujuan-tujuan bersama yang hendak dikejar.

Menurut Boyd (2000:29), strategi didefinisikan sebagai pola fundamental dari tujuan sekarang dan yang akan direncanakan, pengerahan sumber daya, dan interaksi dari organisasi dengan pasar, pesaing, dan faktor-faktor lingkungan, sedangkan menurut Hitt, Ireland, dan Hoskisson (2001:151), strategi adalah serangkaian komitmen dan tindakan yang terintegrasi dan terkoordinasi yang dirancang untuk mengeksploitasi kompetensi inti dan mendapatkan keunggulan kompetitif.

Penelitian ini menggunakan pendekatan deskriptif kualitatif yaitu pengukuran terhadap masalah sosial tertentu khususnya tentang daya tarik wisata. Teknik pengumpulan data adalah sebagai berikut: Data yang dikumpuulkan dengan menggunakan metode observasi ke lokasi penelitian, wawancara mendalam (in-depth interview)) kepada informan. Teknis analisis data menggunakan deskriptif kualitatif, dan analisis matrik SWOT (Strengths, Weakness, Opportunities, Threats).

\section{Kunci Pengembangan di Tangan Pemerintah}

Kunci pengembangan potensi pariwisata di Area Branca Desa Metiaut ada di tangan pemerintah. Destinasi pariwisata Area Branca Desa Metiaut, Dili sangat memiliki potensi daya tarik wisata yang tinggi. Namun, tidak berkembang karena keterbatasan infrastruktur dan kurangnya perencanaan. Peran merupakan aspek dinamis dalam kedudukan (status) terhadap sesuatu. Apabila seseorang melakukan hak dan kewajibannya sesuai dengan kedudukan, maka ia menjalankan suatu peran (Suharto 2006). Sedangkan pemerintah merupakan manifestasi dari kehendak rakyat, karena itu harus memperhatikan kepentingan rakyat dan melaksanakan fungsi pelayanan publik dan pengaturan warga Negara. Ndraha (1987:110) mengatakan bahwa sesungguhnya peranan pemerintah dalam pembangunan masyarakat amat luas, mulai dari hal yang bersifat pelayanan operasional sampai pada hal-hal yang bersifat ideology dan spiritual.

Sehingga untuk menjalankan fungsi dan peran pemerintah yang baik, maka diperlukan peran pemerintah sebagai berikut: 


\section{a. Peran pemerintah dalam membuat regulasi}

Peran pemerintah dalam membuat Regulasi merupakan salah satu faktor terpenting seperti: Undang-undang kepariwisataan, dan peraturanperaturan yang berhubungan dengan perlindungan wisatawan terutama bagi biro perjalanan wisata, peraturan-peraturan tentang retrebusi serta peraturan-peraturan lainnya. Dengan adanya regulasi atau undang-undang ini maka tentunya semua kegiatan yang berhubungan dengan kepariwisataan akan berjalan dengan tertib dan lancar sesuai apa yang diharapkan.

\section{b. Peran pemerintah menyediakan sarana dan prasarana}

Sarana dan prasarana merupakan salah satu elemen yang sangat penting atau sebagai faktor pendukung untuk menarik perhatian wisatawan seperti menyediakan meja, kursi, rumah peristirahatan, menyediakan toilet, memasang lampu dan lain-lainnya.

Sarana adalah perlengkapan pembelanjaran yang dapat dipindahpindah, sedangkan prasarana adalah fasilitas dasar untuk menjalankan fungsi sekolah. Sarana tersebut antara lain seperti gedung, ruang, kelas, meja, kursi serta alat-alat media pembejaran. Yang termasuk prasarana antara lain seperti halaman, taman, lapangan, jalan menuju sekolah dan lain-lain. Dengan adanya sarana dan prasarana yang memadai maka hal ini, akan menarik perhatian wisatawan untuk berkunjung di daya tarik wisata Area Branca Desa Metiaut, Dili.

\section{c. Peran pemerintah membuat perencanaan}

Untuk melaksanakan suatu pekerjaan yang berhasil maka terlebih dahulu perlu peran pemerintah membuat suatu rencana yang lebih matang dulu, hal ini sangat penting agar pekerjaan tersebut bisa berjalan dengan baik sesuai dengan apa yang diinginkan. Pekerjan kalau tidak melalui dengan suatu rencana terlebih dahulu maka pekerjaan tersebut tidak akan berjalan sesuai apa yang diharapkannya.

Menurut Siagian (1994), perencanaan adalah keseluruhan proses pemikiran dan penentuan secara matang daripada hal-hal yang akan dikerjakan di masa yang akan datang dalam rangka pencapaian yang telah ditentukan. Selanjutnya menurut Terry (1975) perencanaan adalah pemilihan dan menghubungkan fakta-fakta, membuat serta menggunakan asumsiasumsi yang berkaitan dengan masa datang dengan menggambarkan dan merumuskan kegiatan-kegiatan tertentu yang diyakini diperlukan untuk mencapai suatu hasil tertentu.

Perencanaan merupakan salah satu proses yang sangat penting dari semua fungsi manajemen karena tanpa perencanaan fungsi-fungsi lain pengorganisasian, pengarahan, dan pengontrolan tidak akan dapat berjalan. 
Rencana dapat berupa rencana informal atau rencana formal. Rencana informal adalah rencana yang tidak tertulis dan bukan merupakan tujuan bersama anggota suatu organisasi. Proses perencanaan mengembangkan lingkungan politik, fisik, sosial dan ekonomi sebagai suatu komponen yang saling terkait dan tergantung dengan yang lainnya (Paturusi, 2008:26).

\section{d. Peran pemerintah melakukan pengawasan}

Pengawasan merupakan salah satu hal terpenting untuk menghubungkan target dengan realisasi setiap program kegiatan proyek yang harus dilaksanakan oleh pemerintah. Suatu pekerjan kalau ingin berjalan secara efisien dan efektif perlu mengadakan pengawasan, kalau tidak maka pekerjaan tersebut pasti tidak akan berkualitas serta pekerjaan itu tentu juga tidak akan selesai pada waktunya. Oleh karena itu peran pemerintah dalam melakukan pengawasan atau pengontrolan ini sangatlah penting.

Menurut Nawawi (1993:6) fungsi pengawasan dapat dilakukan setiap saat, baik selama proses manajemen atau administrasi berlangsung, maupun setelah berakhir, untuk mengetahui tingkat pencapaian tujuan suatu organisasi atau unit kerja. Oleh sebab itu pengawasan sangat penting dilakukan agar bisa mengontrol suatu pekerjaaan itu dengan efektif, kalau tidak maka pekerjaan yang diberikan itu tidak akan terealisir sesuai waktu yang ditetapkannya. Oleh karena itu, penerapan semua peraturan pemerintah dan undang-undang yang berlaku mutlak dilaksanakan oleh pemerintah. Dengan peran pemerintah yang telah disebutkan diatas, maka tentunya masyarakat akan merasa bangga dengan kekayaan alam yang dimilikinya. Area Branca mempunyai banyak tempat wisata yang menakjubkan. Sektor pariwisata di Area Branca Desa Metiaut ini apabila dikembangkan lebih lanjut akan menghasilkan perekonomian yang pesat di Dili, Timor-Leste.

\section{Faktor Pendukung dan Penghambat Peran Pemerintah}

Usaha pengembangan sektor pariwisata di Area Branca Desa Metiaut memiliki faktor pendukung dan penghambat.

\section{a. Faktor Pendukung}

Salah satunya yaitu undang-undang kepariwisataan, ada meskipun belum diterapkan secara baik. Selain itu, adanya dukungan dari masyarakat setempat, lokasinya sangat strategis yaitu dekat dengan kota, minat wisatawan meningkat, serta sudah ada fasilitas yang telah dibangun seperti terlihat pada Foto. 


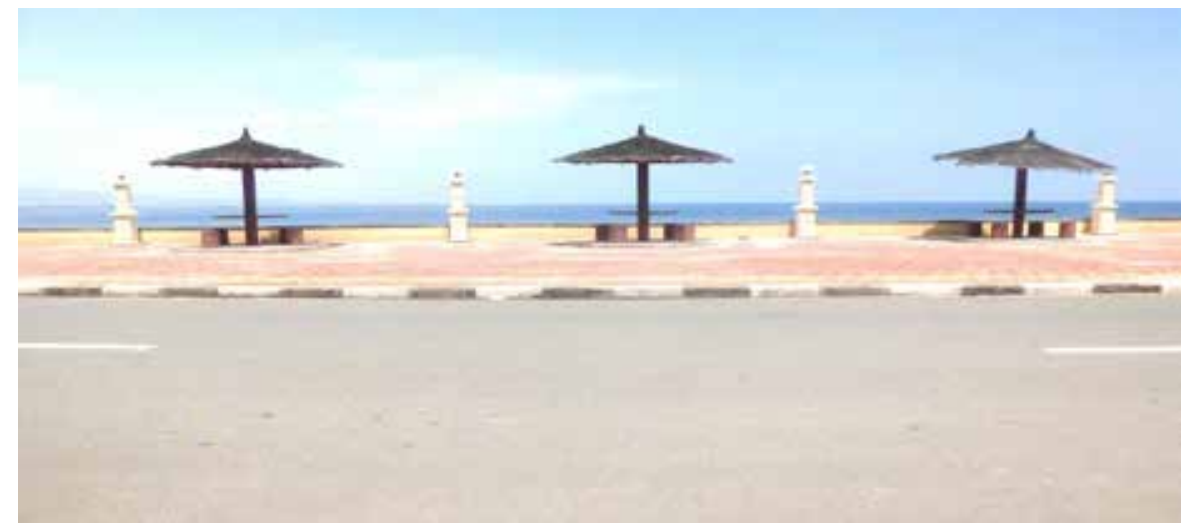

Foto 1 Bangunan rumah peristihatan di Area Branca Desa Metiaut, Dili.

Daya tarik wisata Area Branca Metiaut, Dili sangat cocok digunakan untuk aktivitas rekreasi bagi wisatawan lokal maupun wisatawan asing yang berkunjung di Timor-Leste. Aktivitas yang bisa dinikmati oleh wisatawan di lokasi ini adalah berjemur (sun-bathing) dan bersantai (relax) sambil menikmati sinar matahari dan pemandangan alam pantai. Selain berjemur dan bersantai, wisatawan juga dapat menikmati terbenamnya matahari (sunset) di pantai Area Branca. Lokasi untuk melihat terbenamnya matahari di Area Branca Metiaut, Dili merupakan lokasi yang indah untuk menikmati kejadian alam yang indah di Timor-Leste semisal sunset di Area Branca Metiaut Dili (Foto 2).

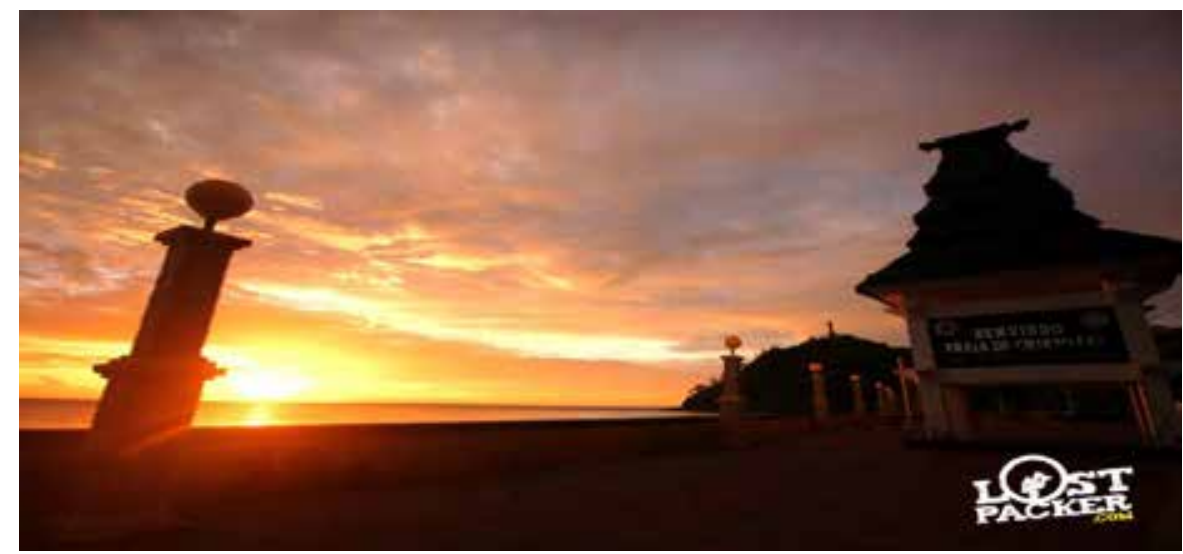

Foto 2 Matahari terbenam (sunset).

Selain daya tarik tersebut sebagai faktor pendukung, ada daya tarik lain yaitu patung Kristus Raja (Foto 3). Patung ini merupakan patung yang besar berbentuk Yesus Kristus dan telah menjadi kebanggaan bagi masyarakat Timor-Leste karena selain sebagai tempat beribadah atau sembahyang, 
patung ini juga dinobatkan sebagai patung Yesus Kristus tertinggi kedua Dunia setelah patung Patung Christ the Redeemer di Rio de Janeiro, Brasil dan tertinggi di Asia.

Foto 3 Patung Kristus Raja

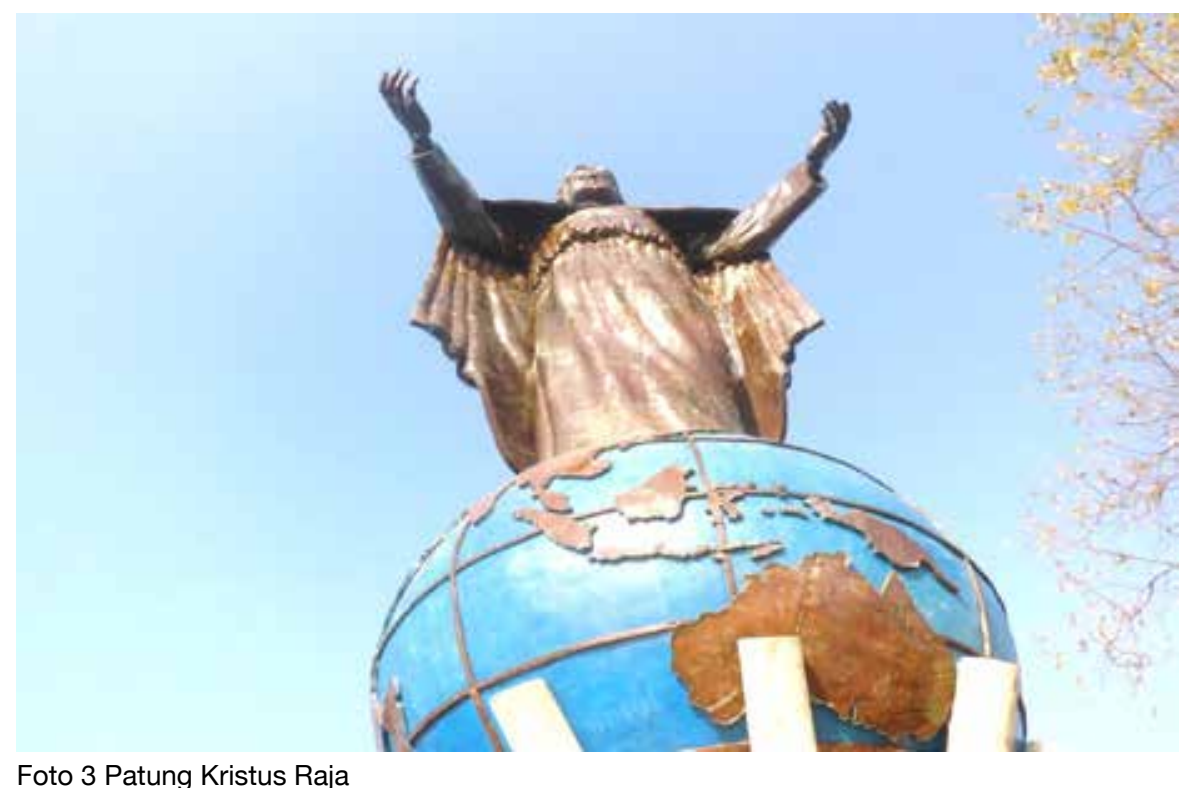

Pada umumnya wisatawan yang berkunjung di destinasi pariwisata Area Branca Desa Metiaut, Dili, langsung mengunjungi patung Kristus Raja untuk melihat-lihat, berfoto, dan sekaligus beribadah atau sembahyang. Patung Cristo Rei memiliki tinggi 27 meter yang memayungi bukit Tanjung Fatucama. Patung ini merupakan hasil karya dari Mochamad Syailillah. Patung Kristus Raja ini menjadi simbol bagi warga untuk menggantungkan harapan akan kedamaian, kesejahteraan, dan kehidupan yang lebih baik di Tanah Lorosae. Patung ini diresmikan pada tanggal 15 Oktober 1996 oleh Presiden Soeharto. Pada masa itu, Dili masih merupakan ibu kota Provinsi ke-27 Timor-Timur, sebelum melepaskan diri pada 20 Mei 2002. Pembuatan patung dikerjakan oleh seniman Mochamad Syailillah, yang akrab disapa Bolil. Baginya, inilah karya besar pertama yang pernah dibuat sebagai pematung. Pembuatannya, memakan waktu hampir satu tahun di Sukaraja, Bandung, Jawa Barat (Joepoet, 2014).

Potensi sebuah daerah untuk berkembang menjadi destinasi wisata tergantung pada beberapa faktor, di antaranya ketersediaan daya tarik wisata, kemudahan daerah dan daya tarik wisata tersebut untuk dijangkau, ketersediaan sarana dan pelayanan wisata dan adanya organisasi kepariwisaan yang menyediakan aturan main serta melakukan pengembangan kepariwisataan di daerah tersebut (Burkart dan Medlik, 
1974; Cooper, 1993). Dari keempat faktor penting tersebut, ketersediaan daya tarik wisata memegang peranan sangat penting. Hal tersebut seperti yang dinyatakan oleh Cooper (1993) bahwa:

"......it is the attraction - whether they be man-made features, natural features or event - that provide the initial motivation to visit"

Pernyataan Cooper (1993) menunjukkan bahwa pengunjung mendatangi sebuah destinasi bukan karena destinasi tersebut memiliki fasilitas ataupun karena kemudahannya untuk dicapai. Pengunjung mendatangi sebuah destinasi karena adanya dorongan (motivasi) untuk melihat sesuatu, baik yang alami maupun buatan manusia. Motivasi ditimbulkan oleh daya tarik dari sebuah destinasi wisata, baik itu daya tarik wisata alam, maupun buatan manusia maupun event.

Pernyataan Cooper (1993: 84), diperkuat oleh pendapat yang disampaikan oleh Mill dan Morrison (2012: 17) yang menyatakan bahwa "The central aspect of tourism are attractions”. Mill dan Morrison mengemukakan pendapatnya berdasarkan pemahaman bahwa daya tarik wisata memiliki kemampuan untuk menarik pengunjung kepadanya. Pariwisata terjadi karena adanya daya tarik yang menarik minat orang-orang yang terdorong untuk berwisata untuk mengunjungi daya tarik wisata tersebut.

\section{b. Faktor Penghambat Pemerintah}

Yang menjadi kendala atau faktor penghambat pemerintah dalam pengembangan Area Branca Metiaut, Dili, menjadi destinasi pariwisata yang indah dapat berjalan dengan efektif dan efisien antara lain ada dua.

Pertama dana yang terbatas, dalam mengembangkan suatu destinasi pariwisata tentunya pemerintah membutuhkan biaya atau anggaran yang besar, Anggaran merupakan salah satu faktor pendukung bagi pemerintah dalam pembuatan suatu rencana baik fisik maupun non fisik semuanya memerlukan anggaran. Namun, anggaran yang selama ini dialokasikan ke pemerintah daerah (PEMDA) jumlahnya sangat terbatas. Sehingga hal ini menjadi salah satu kendala atau faktor penghambat bagi pemerintah untuk mengembangkan daya tarik wisata di Area Branca berkelanjutan.

Kedua sumber daya manusia, destinasi pariwisata tentu pemerintah membutuhkan tenaga-tenaga terampil atau sumber daya manusia (SDM) sebagai faktor pendukungnya, namun hingga saat sumber daya manusia di bidang kepariwisataan masih sangat minim. Hal ini merupakan salah satu faktor penghambat atau kendala bagi pemerintah untuk mengembangkan daerah tujuan wisata tersebut, meski sumber daya alam atau potensi alam sudah mendukung. Sumber daya manusia merupakan salah satu komponen vital bagi pemerintah dalam pengembangan pembangunan pariwisata 
pada umumnya. Sehingga Apa bila sumber daya manusia di destinasi tersebut tidak memadai maka hal ini, akan menjadi faktor atau kendala bagi pemerintah untuk mengembangkan destinasi pariwisata tersebut.

Faktor sumber daya manusia sangat menentukan eksistensi pariwisata. Sebagai salah satu industri jasa, sikap dan kemampuan staff akan berdampak krusial terhadap bagaimana pelayanan pariwisata diberikan kepada wisatawan yang secara langsung akan berdampak pada kenyamanan, kepuasan dan kesan atas kegiatan usaha yang dilakukannya (Pitana dan Diarta, 2009: 72). Dari uraian tersebut, di mana yang pentingnya sebuah sumber daya manusia guna mendukung dan menjalankan roda kepariwisata di suatu destinasi pariwisata termasuk dalam hal pengembangan dan pembangunan destinasi tersebut. Maka, hal tersebut sangat diperlukan untuk mendukung daya saing sebuah destinasi maupun sebagai komponen pendukung dalam pengembangan suatu destinasi secara berkelanjutan.

Penelitian ini menemukan bahwa sebagian besar masyarakat maupun pekerja yang terlibat langsung terhadap perkembangan daya tarik wisata Area Branca baik sebagai karyawan hotel, pemandu wisata (guide) maupun pedagang banyak berinteraksi langsung dengan para wisatawan memiliki tingkat pendidikan rata-rata tamatan Sekolah Dasar (SD) dan Sekolah Menangah Pertama (SMP), bahkan hampir semuanya tidak memiliki latar belakang pendidikan kepariwisataan. Hal tersebut diperkuat dengan keterangan yang disampaikan narasumber dalam penelitian ini, seperti Oficial Dezemvolvimento Comunitario/CDO Bapak Fernando Araujo.

\section{c. Strategi Pemerintah dalam Pengembangan Pariwisata.}

Pengembangan daya tarik wisata, membutuhkan suatu strategi yang baik agar diperoleh hasil yang optimal sesuai dengan tujuan yang ingin dicapai. Untuk menyusun sebuah strategi, analisis SWOT (strength, weakness, opportunities, threat) merupakan pendekatan yang dapat digunakan untuk mengkaji kondisi dan keadaan fisik serta lingkungan di sekitar pantai Area Branca Desa Metiaut, Dili. Strategi tersebut nantinya akan dapat dikembangkan sebagai salah satu masukan dalam kaitan pengembangan daya tarik wisata.

Analisis SWOT digunakan untuk mengetahui kekuatan (strength), kelemahan (weakness), peluang (opportunities) dan ancaman (Threats).

Hasil analisis SWOT mengenai faktor-faktor internal dan eksternal yang ada di daerah tujuan wisata Area Branca menunjukkan bahwa letak posisi Area Branca Metiaut, Dili lebih banyak pada kelemahan (Weakness) dan ancaman (Treasths).

Maka dari itu, pemerintah perlu menciptakan strategi-strategi agar meminimalisirkan kelemahan untuk menghindarikan dari ancaman yang akan dihadapinya, karena Area Branca merupakan daerah tujuan wisata 


\begin{tabular}{|c|c|c|}
\hline & Strengths (S) & Weakness (W) \\
\hline Faktor Eksternal & $\begin{array}{l}\text { 1. Kekayaan alam } \\
\text { 2. Keunikan Sosial budaya } \\
\text { 3. Sikap Ramah-tamah } \\
\text { masyarakat lokal }\end{array}$ & $\begin{array}{l}\text { 1. Objek wisata belum tertata } \\
\text { secara baik } \\
\text { 2. Masih kurangnya masalah } \\
\text { sumber daya manusia (SDM) di } \\
\text { bidang kepariwisataan } \\
\text { 3. Undang-undang kepariwisataan } \\
\text { belum diterapkannya } \\
\text { 4. Belum adanya kerjasama yang } \\
\text { baik antara pemerintah dengan } \\
\text { masyarakat }\end{array}$ \\
\hline Opportunities (O)Peluang & $\begin{array}{c}\text { Strategi S-O } \\
\text { Strategi yang menggunakan } \\
\text { kekuatan untuk memanfaat- } \\
\text { kan Peluang }\end{array}$ & $\begin{array}{c}\text { Strategi S-T } \\
\text { Strategi yang meminimal- } \\
\text { kan untuk memanfaatkan } \\
\text { peluang }\end{array}$ \\
\hline $\begin{array}{l}\text { 1. Meningkatnya minat Wisatawan } \\
\text { di Area branc, Dili } \\
\text { 2. Jarak Area Branca tidak jauh } \\
\text { dari kota dengan Bandara In- } \\
\text { ternasional Dili ibu kota Negara } \\
\text { Timor Leste }\end{array}$ & $\begin{array}{l}\text { 1. Strategi paket wisata: } \\
\text { alam,sejarah, sosial budaya dan } \\
\text { bahari. } \\
\text { 2. Peningkatan kualitas Sumber } \\
\text { Daya Manusia }\end{array}$ & $\begin{array}{l}\text { 1. Strategi penerapan hukum yang } \\
\text { tegas } \\
\text { 2. Strategi meningkatkan } \\
\text { keamanan khususnya di Area } \\
\text { Branca, Dili }\end{array}$ \\
\hline Treasths (T) & Strategi S-T & Strategi W-T \\
\hline $\begin{array}{l}\text { 1. Masyarakat melakukan pen- } \\
\text { ebangan pohon dan membakar } \\
\text { didaerah sekitarnya } \\
\text { 2. Kondisi keamanan yang masih } \\
\text { kurang melebar luas di sudut- } \\
\text { sudut daerah objek wisata di } \\
\text { Area Branca, Dili } \\
\text { 3. Kurangnya dukungan atau } \\
\text { perhatian yang serius dari } \\
\text { pemerintah } \\
\text { 4. Belum adanya sarana dan } \\
\text { prasarana penunjang pariwisata } \\
\text { yang memadai } \\
\text { 5. Persaingan destinasi wisata } \\
\text { yang sejenis banyak didaerah } \\
\text { lainnya. }\end{array}$ & $\begin{array}{l}\text { 1. Strategi penerapan hukum yang } \\
\text { tegas } \\
\text { 2. Meningkatkan kemanan khu- } \\
\text { susnya di Area Branca, Dili }\end{array}$ & $\begin{array}{l}\text { 1. Strategi peningkatan SDM } \\
\text { 2. Strategi penyuluhan sadar } \\
\text { wisata atau melakukan sosial- } \\
\text { isasi } \\
\text { 3. Strategi membangun fasilitas } \\
\text { umum di daerah tujuan wisata } \\
\text { Area Branca, Dili }\end{array}$ \\
\hline
\end{tabular}

yang diperhitungkan di Kabupaten Dili negara Timor-Leste karena memiliki kekuatan akan potensi-potensi wisata berupa alam, budaya dan sejarah.

\section{Program berdasarkan strategi Weakness Threats}

Strategi merupakan salah satu cara untuk mencapai suatu tujuan berdasarkan analisis terhadap faktor internal dan eksternal. Oleh sebab itu, sesuai dengan perencanaan, perumusan strategi sebaiknya diikuti oleh suatu rencana konkret yang disebut program, jika ada anggaran maka dapat direalisasikan menjadi suatu program proyek.

\section{Program berdasarkan Strategi (Weakness Threats)}

Strategi ini berupaya untuk meminimalisir kelemahan dan ancaman dalam pengembangan pariwisata di Area Branca Metiaut, Dili yaitu:

\section{Pertama Strategi Peningkatan Sumber Daya Manusia}

Peningkatan sumber daya manusia di bidang pariwisata dapat dilakukan melalui jalur pendidikan formal dan nonformal yaitu: Pertama, jalur formal dilakukan melalui mendirikan sekolah tinggi pariwisata dengan memberikan 
Program Pengembangan Pariwisata di Area Branca Metiaut, Dili

\begin{tabular}{ccc}
\hline \multicolumn{1}{c}{ Strategi } & \multicolumn{1}{c}{ Program } \\
\hline $\mathbf{W}-\mathbf{T}$ & $\begin{array}{c}\text { Strategi pengembangan kelembagaan dan } \\
\text { Sumber Daya Manusia (SDM) }\end{array}$ & $\begin{array}{l}\text { 1. Memberikan beasiswa } \\
\text { 2. Program pembentukan kelembagaan } \\
\text { pengelola daya tarik wisata }\end{array}$ \\
\hline $\begin{array}{c}\text { Strategi penyuluhan Sadar wisata atau } \\
\text { sosialisasi }\end{array}$ & $\begin{array}{l}\text { 1. Mengadakan sosialisasi atau peny- } \\
\text { uluhan tentang sadar wisata kepada } \\
\text { masyarakat }\end{array}$ \\
& $\begin{array}{l}\text { 2. Kursus-kursus terkait dengan kepari- } \\
\text { wisataan }\end{array}$ \\
\hline Strategi membangun Fasilitas & $\begin{array}{l}\text { 1. Pengembangan akomodasi } \\
\text { 2. Pengembangan rumah makan }\end{array}$ \\
& $\begin{array}{l}\text { 3. Penyediaan souvenirshop (Cender- } \\
\text { amata) }\end{array}$ \\
\hline
\end{tabular}

beasiswa. Kedua, jalur nonformal dapat dilakukan melalui pelatihanpelatihan di industri pariwisata hotel maupun restoran dan kursus-kursus singkat di bidang kepariwisataan.

\section{Kedua Penyuluhan Sadar wisata atau sosialisasi}

Pariwisata merupakan suatu aktivitas yang secara langsung menyentuh dengan melibatkan masyarakat, sehingga hal ini, akan membawa dampak terhadap masyarakat setempat. Masyarakat di Area Branca masih ada sebagian belum termasuk masyarakat yang sadar wisata, dalam arti belum memiliki kesiapan mental untuk menerima dan melayani para wisatawan. Sehingga untuk mengantisipasi kunjungan para wisatawan tersebut, maka perlu diberikan suatu penyuluhan tentang aspek-aspek sadar wisata yang diberikan oleh pemerintah dan lembaga-lembaga yang bergerak di bidang pariwisata seperti: kerahmatamahan keamanan dan kenyamanan, keterlibatan atau keikutsertaan, masalah kebersihan, kemudahan dan kesejukan.

Dalam pengembangan pariwisata di Area Branca apabila tidak melalui cara pembianaan atau penyuluhan mengenai kepariwisataan kepada masyarakat, maka dikhawatirkan akan terjadinya hal-hal yang berdampak negatif terhadap kunjungan atau kedatangan para wisatawan. Oleh karena itu, masyarakat diberikan pembinaan dan penyuluhan untuk menyadarkan akan pentingnya kepariwisataan, sehingga masyarakat akan ikut memberikan dukungan yang positif terhadap kepariwisataan serta mempunyai rasa memiliki, sebab dengan berkembangnya pariwisata dan kunjungan wisatawan semakin meningkat maka secara otomatis akan ada perubahan sosial bagi masyarakat di daerah tersebut.

\section{Ketiga Program Pengembangan Fasilitas}

Pengembangan pembangunan fasilitas atau sarana dan prasarana penunjang pariwisata adalah salah satu program yang sangat penting dibutuhkan dalam upaya memberikan kenyamanan dan pelayanan untuk 
wisatawan yang ingin berkunjung ke daerah tersebut.

Menurut Hang (2011:82) bahwa untuk mengatasi kelemahan dan mengoptimalkan peluang yang ada layaknya, membuat suatu program strategi pembangunan infrastruktur yang lebih baik untuk memenuhi dan meningkatnya wisatawan dengan peningkatan daerah wisata. Dengan hal ini, aktivitas di Area Branca Desa Metiaut, Dili layak dilakukan dalam pendukung program pembangunan pariwisata ini antara lain seperti penambahan akomodasi, restoran, penyediaan souvenirshop (cenderamata). Cenderamata merupakan satu salah unsur untuk memenuhi kebutuhan wisatawan sebagai suatu kenangan.

Area Branca memiliki kekayaan akan kerajinan hasil produk antara lain seperti: tenunan selendan (tais), anyaman dan ukir-ukiran (arte senato). Dengan adanya kekayaan ini, maka perlu suatu program strategi pengembangan seperti penyediaan souvenir shop dapat menjawab beberapa persoalan.

\section{Simpulan}

Berdasarkan analisis di atas, dapat disimpulkan hal-hal sebagai berikut. Pengembangan Area Branca Metiaut sebagai daerah wisata menghadapi faktor pendukung dan hambatan. Faktor Pendukung Area Branca Metiaut sebagai sebuah daerah tujuan wisata yang memiliki daya tarik utama berupa pemandangan alam pantai yang landai indah, dengan pasir yang berwarna putih. Hal ini menjadi faktor pendukung pemerintah untuk mengembangkan pariwisata di Pasir Putih. Daya tarik wisata Pasir Putih Cristo Rei, Dili sangat cocok digunakan untuk kegiatan rekreasi bagi wisatawan baik wisatawan domestik maupun wisatawan mancanegara yang berkunkjung di TimorLeste. Kegiatan yang bisa dinikmati oleh wisatawan di lokasi ini adalah berjemur (sun-bathing) dan bersantai (relax).

Faktor penghambat dalam pengembangan pariwisata di Area Branca Metiaut meliputi dana terbatas, kurangnya sumber daya manusia, kurangnya kesadaran masyarakat, kurangnya kerja sama antara pemerintah dengan masyarakat, dan masih kurangnya fasilitas pendukung

Strategi pengembangan yaitu perlunya strategi peningkatan sumber daya manusia, perlu memberikan penyuluhan sadar wisata atau sosialisasi untuk masyarakat, pengembangan fasilitas seperti penambahan akomodasi, penambahan restoran dan perlu penyediaan souvenir (cenderamata).

\section{Ucapan Terima kasih}

Pada kesempatan ini penulis hendak menyampaikan terima kasih sebesar-besarnya kepada Bapak Dr. Ir. Syamsul Alam Paturusi, MSP selaku pembimbing I juga selaku Sekretaris Program Studi Magister Kajian Pariwisata Program Pascasarjana Universitas Udayana dan Bapak Dr. Ida 
Bagus Ketut Surya, SE.,MM selaku pembimbing II atas waktu, perhatian, semangat dan kesabarannya dalam memberikan bimbingan, masukan, koreksi dan saran yang sangat membantu penullis dalam penyusunan dan penyelesaian tesis ini. Ucapan terima kasih juga disampaikan kepada para dosen penguji yaitu Bapak Prof. Dr. I Nyoman Darma Putra, M.Litt., Bapak Prof. Made Sudiana Mahendra, MApp. Sc. PhD., dan Bapak Dr. Dewa Putu Oka Prasiasa, MM, yang telah banyak memberikan perhatian, kritik dan saran demi kesempurnaan tesis ini.

\section{Daftar Pustaka}

Boyd, Harper, 2000. Manajemen Pemasaran: Suatu Pendekatan Strategis Dengan Orientasi Global. Jakarta: Erlangga.

Campbell, Mitchell, Reece. 1994. Biology Concepts \& Connections. The Benjamin/ Cummings Publishing Company, Inc.

Cooper, Crist. 1993. Tourism Principles and Practices. Pitaman: Britain

Hang, Chandaravuth and Song Sothun. 2011. Potential For Developing Tourism In

Banteay Chhmar. Cambodia: Royal University of Agriculture, [Cited 2015 Aug. 25]. From: URL: http:/www.jurnalinternational.com/htm.

Hitt, Michael A, Ireland, dan Hoskisson. 2001. "Majajemen Strategis: Daya Saing dan Globalisasi”, (tesis) Denpasar, Universitas Udayana.

Ndraha. 1987. Peranan Pemerintah. Diakses 5 Januari 2016. Tersedia pada: CAFEBISNIS.com.

Paturusi, Syamsul Alam, 2008. Perencanaan Kawasan Pariwisata. Denpasar: Udayana University Press.

Pitana, I Gde dan Diarta, I Ketut Surya. 2009. Pengantar Ilmu Pariwisata. Yogyakarta: Andi.

Suharto, Edi. 2006. Membangun Masyarakat Memberdayakan Rakyat. Bandung:

Refika Aditama.

Undang-Undang Republik Demokrat Timor-Leste (Konstitusi Republica Democratica de Timor- Leste, RDTL, 2002).

Yoeti, Oka A. 2008. Perencanaan dan Pengembangan. Jakarta: Pradnya Paramita.

\section{Profil Penulis}

Zeferino Martins, S.I.P.,M. Par. menyelesaikan studi master di Program Studi Magister Kajian Pariwisata Universitas Udayana tahun 2016. Lulusan S1 pada Jurusan Ilmu Pemerintahan, Fakultas Ilmu Sosial dan Ilmu Politik di Universitas Nasional Timor-Lorosa'e tahun 2006 ini pernah bekerja sebagai Pegawai Negeri Sipil di Departemen Perindustrian dan Perdagangan di Lampung Indonesia. Tahun 20002009 sebagai Kepala Bagian Administrasi di Fakultas Pertanian Universitas Nasional Timor-Lorosa'e. Tahun 2009-2012 menjabat sebagai Direktur Nasional Administrasi dan Keuangan di Kementerian Ekonomi dan Pembangunan Timor-Leste. Tahun 
2012-2014 menjabat sebagai Direktur Nasional Perlengkapan di Kementerian Pariwisata dan Seni Budaya Timor-Leste. Email: zmartins70@yahoo.com

Dr. Ir. Syamsul Alam Paturusi, MSP adalah dosen Prodi Magister Kajian Pariwisata, saat ini menjabat sebagai sekretaris program studi Magister Kajian Pariwisata, Universitas Udayana. Selain itu, beliau juga aktif mengajar sebagai dosen Magister Teknik Arsitek di Universitas Udayana, Denpasar, Bali. Beliau berasal dari Makasar, Sulawesi Selatan, yang lahir dan dibesarkan di keluarga besar Paturusi. Program pendidikan yang sudah ditempuh yaitu Sarjana (S1) di Arsitektur Universitas Hasanuddin, Makasar, jenjang Magister (S2) di PWK ITB, Bandung, dan jenjang Doktor (S3) di Université de Pau et des Pays de 1,Adour, Prancis. Email: syamsul@ unud.ac.id

Dr. Ida Bagus Ketut Surya, SE., MM adalah dosen Prodi Magister Kajian Pariwisata Universitas Udayana. Selain itu, beliau juga aktif megajar sebagai dosen Program Studi Manajemen pada Fakultas Ekonomi dan Bisnis Universitas Udayana, Prodi Magister Manajemen, Prodi Magister Akuntansi dan Prodi Doktor Ilmu Manajemen Universitas Udayana. Beliau lahir di Desa Lukluk, Kecamatan Mengwi, Kabupaten Badung. Program pendidikan yang ditempuh yaitu Sarjana (S1) di Manajemen Fakultas Ekonomi dan Bisnis Universitas Udayana, jenjang (S2) di Magister Manajemen Konsentrasi Bisnis Pariwisata di Universitas Udayana, dan jenjang Doktor (S3) di Program Doktor Ilmu Manajemen Universitas Brawijaya Malang. Email: idabgssurya@unud.ac.id 